\title{
CD8-Positive Neoplastic Cells Present
}

National Cancer Institute

\section{Source}

National Cancer Institute. CD8-Positive Neoplastic Cells Present. NCI Thesaurus. Code C45324.

An indication that expression of CD8 has been detected in a sample of neoplastic cells. 